\title{
Metabolic reprogramming: a new relevant pathway in adult adrenocortical tumors
}

\author{
Céline Pinheiro ${ }^{1,2,3,4, *}$, Sara Granja ${ }^{1,2, *}$, Adhemar Longatto-Filho ${ }^{1,2,4,5}$, André M. \\ Faria $^{6}$, Maria C. B. V. Fragoso ${ }^{6,7}$, Silvana M. Lovisolo ${ }^{8}$, Antonio M. Lerário7, Madson \\ Q. Almeida ${ }^{6,7}$, Fátima Baltazar ${ }^{1,2, *}$, Maria C. N. Zerbini ${ }^{9, *}$ \\ ${ }^{1}$ Life and Health Sciences Research Institute (ICVS), School of Health Sciences, University of Minho, Braga, Portugal \\ ${ }^{2}$ ICVS/3B's-PT Government Associate Laboratory, Braga/Guimarães, Portugal \\ ${ }^{3}$ Barretos School of Health Sciences Dr. Paulo Prata - FACISB, Barretos, Sao Paulo, Brazil \\ ${ }^{4}$ Molecular Oncology Research Center, Barretos Cancer Hospital, Barretos, Sao Paulo, Brazil \\ ${ }^{5}$ Laboratory of Medical Investigation (LIM-14), Faculdade de Medicina da Universidade de São Paulo, São Paulo, Brazil \\ 'Unidade de Suprarrenal, Disciplina de Endocrinologia e Metabologia, Laboratório de Hormônios e Genética Molecular LIM42, \\ Hospital das Clínicas, Faculdade de Medicina da Universidade de São Paulo, São Paulo, Brazil \\ ${ }^{7}$ Instituto do Câncer do Estado de São Paulo - ICESP, Hospital das Clínicas, Faculdade de Medicina da Universidade de São \\ Paulo, São Paulo, Brazil \\ ${ }^{8}$ Hospital Universitário, Faculdade de Medicina da Universidade de São Paulo, São Paulo, Brazil \\ ${ }^{9}$ Departamento de Patologia, Faculdade de Medicina da Universidade de São Paulo, São Paulo, Brazil \\ *These authors have contributed equally to this work \\ Correspondence to: \\ Céline Pinheiro, e-mail: celinepinheiro@gmail.com \\ Keywords: adrenocortical tumors, metabolic reprogramming, monocarboxylate transporter, Warburg effect \\ Received: May 09, $2015 \quad$ Accepted: November 06, $2015 \quad$ Published: November 16, 2015
}

\section{ABSTRACT}

Adrenocortical carcinomas (ACCs) are complex neoplasias that may present unexpected clinical behavior, being imperative to identify new biological markers that can predict patient prognosis and provide new therapeutic options. The main aim of the present study was to evaluate the prognostic value of metabolism-related key proteins in adrenocortical carcinoma. The immunohistochemical expression of MCT1, MCT2, MCT4, CD147, CD44, GLUT1 and CAIX was evaluated in a series of 154 adult patients with adrenocortical neoplasia and associated with patients' clinicopathological parameters. A significant increase in was found for membranous expression of MCT4, GLUT1 and CAIX in carcinomas, when compared to adenomas. Importantly MCT1, GLUT1 and CAIX expressions were significantly associated with poor prognostic variables, including high nuclear grade, high mitotic index, advanced tumor staging, presence of metastasis, as well as shorter overall and disease free survival. In opposition, MCT2 membranous expression was associated with favorable prognostic parameters. Importantly, cytoplasmic expression of CD147 was identified as an independent predictor of longer overall survival and cytoplasmic expression of CAIX as an independent predictor of longer disease-free survival. We provide evidence for a metabolic reprogramming in adrenocortical malignant tumors towards the hyperglycolytic and acid-resistant phenotype, which was associated with poor prognosis.

\section{INTRODUCTION}

Adrenocortical carcinoma (ACC) is a rare and highly aggressive malignancy with an annual incidence of 0.7-2.0 cases per million [1-3]. Surgery is the standard of care for localized adrenocortical carcinomas. To date, systemic treatment of advanced ACC has shown unsatisfactory overall response $[4,5]$. Over the past two decades, considerable advances have been made into the understanding of molecular mechanisms, but is still not yet satisfactory $[1,2,6]$.

Adrenocortical neoplasms have been a great challenge since they may present an unexpected biological 
behavior when using classic features commonly used for histopathological classification of neoplastic lesions, particularly in the borderline Weiss (scores 3 and 4) group. Therefore, it is imperative to find alternative information that can help determine with greater accuracy the possible biological behavior of patients with this disease, and, consequently, establish a correct therapeutic strategy $[7,8]$.

During carcinogenesis and tumor progression, neoplastic cells may reprogram their metabolism, showing a preference for glycolysis pathway for energy production, even in the presence of oxygen, a phenomenon known as the "Warburg effect". This aerobic glycolysis implies the conversion of pyruvate to lactic acid, leading to a reduction in intracellular $\mathrm{pH}$ [9]. To prevent acid-induced apoptosis as well as glycolysis inhibition by accumulation of the end product, cancer cells upregulate proteins related to $\mathrm{pH}$ regulation and lactate transport, including the glucose transporter GLUT1, the $\mathrm{pH}$ regulator carbonic anhydrase IX (CAIX) [10, 11] and monocarboxylate transporters (MCTs) [11]. Therefore, many malignancies show a significant increase in the expression of these plasma membrane transporters, with associations with poor patient's prognosis [12-15]. The MCT family has 14 members, being isoforms 1,2 and 4 the most well studied isoforms responsible for the transport of monocarboxylates, including lactate, coupled with a proton across the plasma membrane. As consequence from their substrate affinities, MCT1 and MCT4 mediate monocarboxylate efflux from cells, while MCT2 is involved in monocarboxylate uptake [16]. Importantly, these transporters require co-expression with chaperones for proper plasma membrane localization and activity. The main chaperone of MCT1 and MCT4 is CD147 [17, 18], while MCT2 is mainly associated with gp70 [18]. CD44 has also been recently described as a MCT chaperone [19]; however CD147 and CD44 expressions do not account for all MCT1/4 positive cases, suggesting that an additional MCT chaperone still remains to be identified [20].

To the best of our knowledge, the metabolic profile of adrenocortical tumors is very little explored [21]. However, ${ }^{18} \mathrm{~F}$-fluorodeoxyglucose positron emission tomography (FDG-PET) data suggest that adrenocortical carcinomas show high levels of glucose consumption [22-25], indicating a possible clinical relevance of the glycolytic metabolism for the management of this neoplasia. Given the importance of these neoplasms, particularly in the Brazilian environment [26, 27], and the potential use of molecular players of aerobic glycolysis as prognostic tools and therapeutic targets $[10,12,28]$, the aim of the present work is to study the pattern of expression of the metabolism-related proteins MCT1, MCT2, MCT4, their chaperones CD147 and CD44, as well as GLUT1 and CAIX in adult ACC, and to determine whether these proteins have some biological and/or prognostic predictive value.

\section{RESULTS}

\section{Expression of MCTs, CD147, CD44, GLUT1 and CAIX in adrenocortical adenomas and carcinomas}

The immunohistochemical evaluation of these metabolism-related proteins in adrenocortical adenomas and carcinomas shows that all proteins can exhibit cytoplasmic, plasma membrane or simultaneous expression in both localizations, with a predominance of plasma membrane expression (exception for CAIX, Figures 1 and 2). As can be seen in Figure 2, all 3 MCT isoforms were expressed in the plasma membrane of most adrenocortical carcinoma samples (around 60-65\%) and, MCT4 expression was significantly higher in carcinomas than in adenoma cells (66.7\% versus $20.0 \%$, respectively, $p<0.001$ ). Cytoplasmic expression frequencies were more heterogeneous among MCT isoforms and did not differ between adenomas and carcinomas. CD147 was the protein more frequently expressed in the plasma membrane, but, similarly to CD44, no significant difference was observed between adenomas and carcinomas (Figure 2). In the carcinoma group, an increased expression was observed in the cytoplasm and plasma membrane for GLUT1 $(p<0.001$ and $p<0.001$, respectively, Figure 2), as well as in the plasma membrane for CAIX ( $p<0.001$, Figure 2). When evaluating the co-expression of MCTs with the other proteins at the plasma membrane (Table 1), we found co-expression of MCT1 and either CD147 $(p=0.001)$ or GLUT1 $(p=0.007)$, MCT2 co-expressed positively with CD147 $(p<0.001)$ and inversely with CAIX ( $p=0.023)$, and MCT4 co-expressed with CD147 $(p=0.005)$, CD44 $(p=0.031)$, GLUT1 $(p=0.001)$ and CAIX $(p<0.001)$.

\section{Clinicopathological significance of the metabolism-related proteins}

The analysis of MCT plasma membrane expression association with the clinicopathological parameters is shown in Table 2. MCT1 was significantly associated with stage III $+\mathrm{IV}(p=0.029)$, MCT2 was significantly associated with smaller tumor size $(p=0.004)$, lower mitotic index $(p=0.008)$, absence of sinus invasion $(p=0.024)$ and absence of metastasis $(p=0.022)$, while MCT4 showed no significant associations with the clinicopathological data. Table 3 shows the associations of CD147, CD44, GLUT1 and CAIX plasma membrane expression with the clinicopathological parameters. CD147 was significantly associated with smaller tumor size $(p=0.009)$, GLUT1 was significantly associated with higher mitotic index $(p=0.011)$ and presence of metastasis $(p=0.004)$, CAIX was significantly associated with higher nuclear grade $(p=0.048)$ and presence of metastasis ( $p=0.021)$, while CD44 showed no significant associations with the clinicopathological data. When 


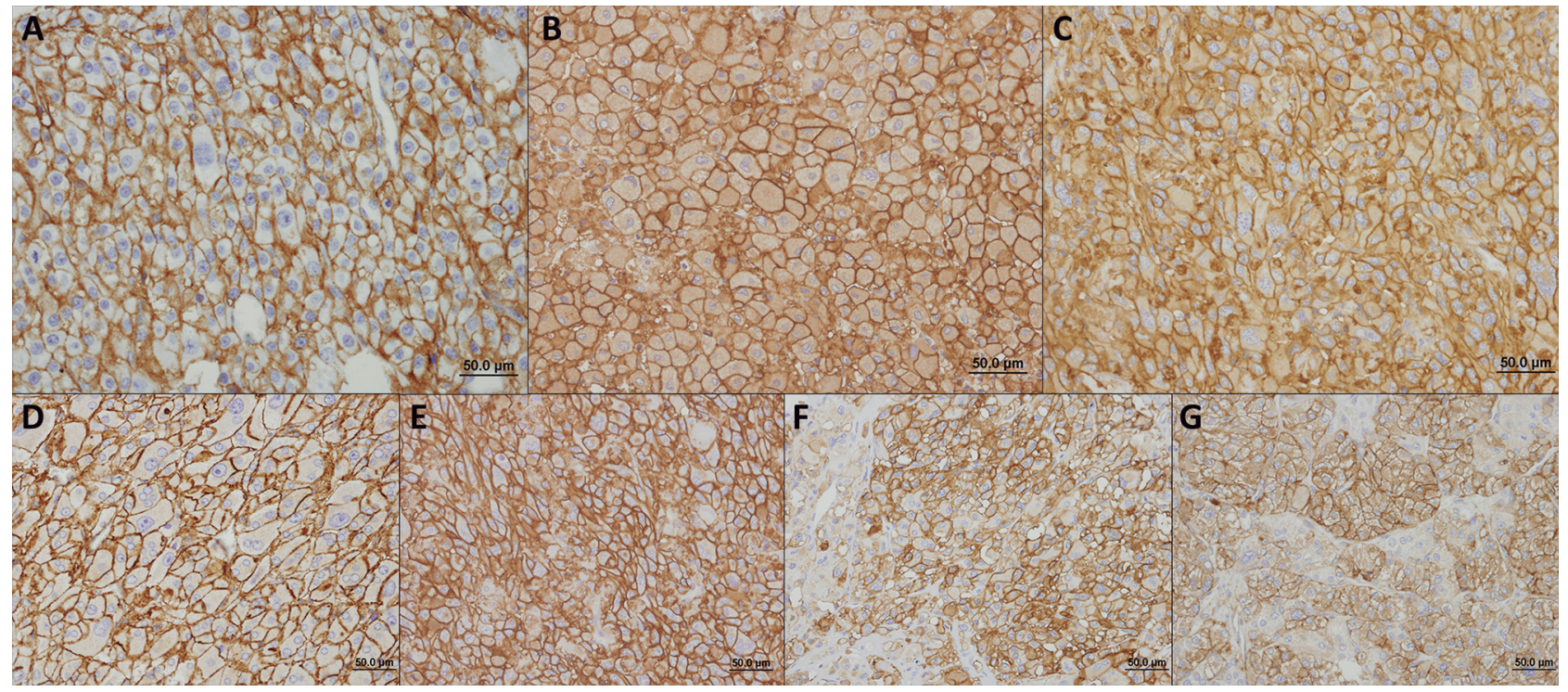

Figure 1: Immunohistochemical expression of MCT1 A. MCT2 B. MCT4 C. CD147 D. CD44 E. GLUT1 F. and CAIX G. in adrenocortical carcinomas. All the proteins were more importantly found in the plasma membrane of cells.

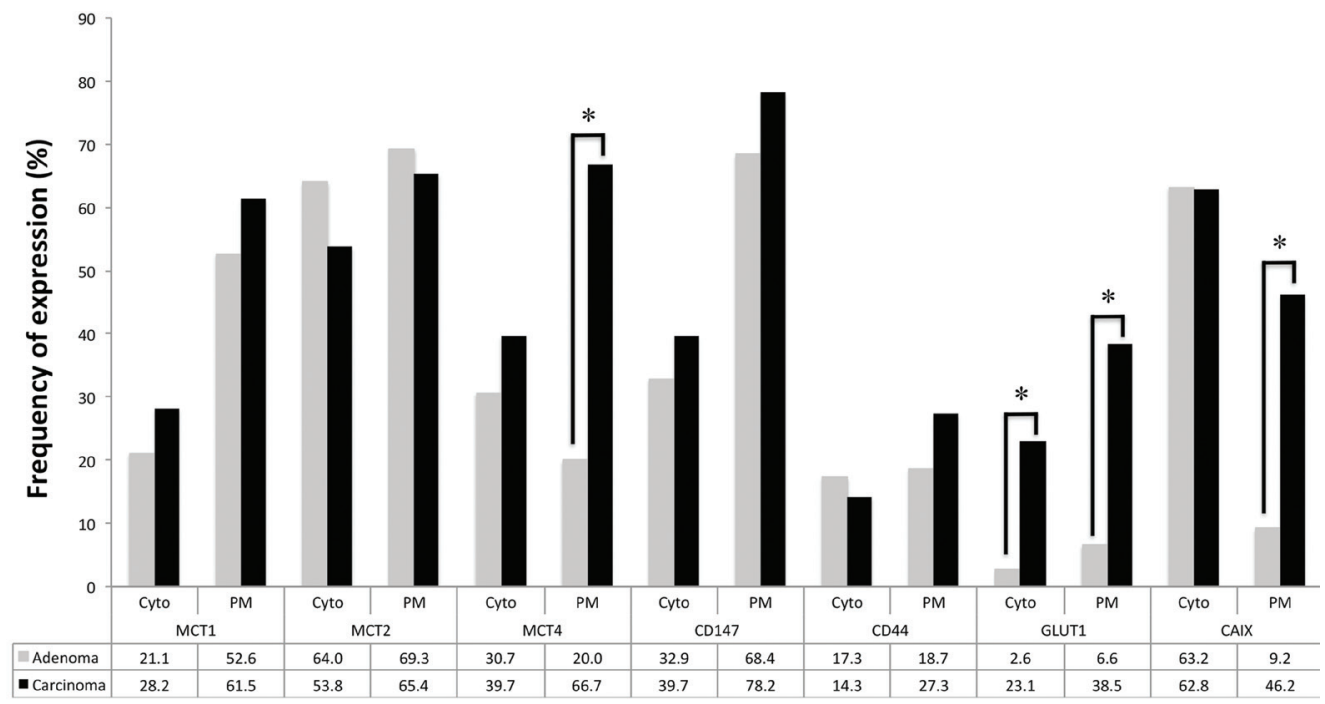

Figure 2: Frequency of staining of the different proteins analyzed in adrenocortical adenomas and carcinomas. Pearson's chi-square $\left(\chi^{2}\right)$ test was used to assess differences of expression frequency between adenomas and carcinomas. ${ }^{*} p<0.001$

evaluating the cytoplasmic expression of the proteins under study, MCT4 and CD147 were significantly associated with absence of metastasis and CAIX with absence of necrosis (data not shown).

\section{Survival analysis}

Overall survival analysis (Figure 3) shows MCT1 and GLUT1 plasma membrane expression significantly associated with shorter overall survival $(p=0.033$ and $p=0.005$, respectively), MCT2 plasma membrane expression significantly associated with longer overall survival ( $p=0.009)$, a tendency for CD147 cytoplasmic expression to be associated with longer overall survival ( $p=0.058$, data not shown) and CAIX plasma membrane expression associated with shorter overall survival $(p=0.051)$. Disease-free survival analysis (Figure 4) shows MCT4, CD147 and CAIX cytoplasmic expression to be significantly associated with longer diseasefree survival $(p=0.045, p=0.019$ and $p=0.045$, respectively), GLUT1 plasma membrane expression associated with shorter disease-free survival $(p=0.007)$ and a tendency for CAIX plasma membrane expression to be associated with shorter disease-free survival ( $p=0.064$, data not shown). The predictive prognostic values of the proteins were analyzed by means of Cox 
Table 1: Co-expression of MCTs with CD147, CD44, GLUT1 and CAIX, in adult adrenocortical tumor samples (adenomas and carcinomas). Only plasma membrane expressions were considered

\begin{tabular}{|c|c|c|c|c|c|c|c|c|c|c|c|}
\hline & \multicolumn{3}{|c|}{ CD147 } & \multicolumn{3}{|c|}{ CD44 } & & \multicolumn{2}{|c|}{ GLUT1 } & \multicolumn{2}{|c|}{ CAIX } \\
\hline & $n$ & $\begin{array}{c}\text { Positive } \\
\text { (\%) }\end{array}$ & $p$ & $n$ & $\begin{array}{c}\text { Positive } \\
\text { (\%) }\end{array}$ & $p$ & $n$ & $\begin{array}{c}\text { Positive } \\
(\%)\end{array}$ & $p$ & $\begin{array}{c}\text { Positive } \\
(\%)\end{array}$ & $p$ \\
\hline MCT1 & & & 0.001 & & & 0.122 & & & 0.007 & & 0.108 \\
\hline Negative & 66 & $\begin{array}{c}39 \\
(59.1)\end{array}$ & & 65 & $11(16.9)$ & & 66 & $8(12.1)$ & & $14(21.2)$ & \\
\hline Positive & 88 & $\begin{array}{c}74 \\
(84.1)\end{array}$ & & 87 & $24(27.6)$ & & 88 & $\begin{array}{c}27 \\
(30.7)\end{array}$ & & $29(33.0)$ & \\
\hline MCT2 & & & $<0.001$ & & & 0.150 & & & 0.293 & & 0.023 \\
\hline Negative & 50 & $\begin{array}{c}26 \\
(52.0)\end{array}$ & & 50 & $8(16.0)$ & & 50 & $\begin{array}{c}14 \\
(28.0)\end{array}$ & & $20(40.0)$ & \\
\hline Positive & 103 & $\begin{array}{c}87 \\
(84.5)\end{array}$ & & 102 & $27(26.5)$ & & 103 & $\begin{array}{c}21 \\
(20.4)\end{array}$ & & $23(22.3)$ & \\
\hline MCT4 & & & 0.005 & & & 0.031 & & & 0.001 & & $<0.001$ \\
\hline Negative & 86 & $\begin{array}{c}56 \\
(65.1) \\
\end{array}$ & & 85 & $14(16.5)$ & & 86 & $11(12.8)$ & & $13(15.1)$ & \\
\hline Positive & 67 & $\begin{array}{c}57 \\
(85.1)\end{array}$ & & 67 & $21(31.3)$ & & 67 & $\begin{array}{c}24 \\
(35.8)\end{array}$ & & $30(44.8)$ & \\
\hline
\end{tabular}

proportional hazards regression models (Table 4). Univariate analysis showed similar results to the ones obtained with Kaplan-Meier analysis. Multivariate analysis showed that CD147 cytoplasmic expression was the only factor with predictive value for overall survival, with a hazard ratio of $0.32(p=0.008)$, and that CAIX cytoplasmic expression was the only factor with predictive value for disease-free survival, with a hazard ratio of $0.31(p=0.036)$. Tumor stage according to ENSAT system confirmed to be a strong prognostic factor for both overall survival and disease-free survival in the univariate and multivariate analysis.

\section{Glycolytic versus oxidative phenotype}

The major findings described so far allowed us to establish 2 predominant expression profiles, the glycolytic and the oxidative phenotypes (summarized in Figure 5), which were associated with the clinicopathological parameters. The staining patterns of the metabolismrelated proteins in cases representative of the glycolytic and oxidative phenotypes are shown in Figure 6 and Figure 7, respectively. The glycolytic phenotype was significantly associated with the mitotic index of the cases $[8.3 \%(2 / 24)$ of cases with low mitotic index show a glycolytic phenotype versus $35.3 \%$ (6/17) of cases with high mitotic index; $p=0.049$ ] and tumor $\mathrm{p} 53$ status [10.5\% (2/19) of cases with normal p53 show a glycolytic phenotype versus $80.0 \%$ (4/5) of cases with mutated $\mathrm{p} 53$; $p=0.006]$.

\section{DISCUSSION}

The increased frequency of MCT4, GLUT1 and CAIX plasma membrane expression of in adrenal cortical carcinomas suggests a metabolic remodeling of malignant cells towards a hyperglycolytic and acidresistant phenotype, which is compatible with data from FDG-PET [22-25]. MCT2, mainly responsible for the uptake of monocarboxylates into cells [16], as expected, showed a slight but not significant decrease in the frequency of expression from adenomas to carcinomas, which is compatible with the metabolic reprogramming towards aerobic glycolysis in carcinomas. Although CD147 and CD44 showed no increase in expression in carcinomas, they were more frequently expressed in MCT positive tumors, which is in accordance with their role as MCT chaperones [17-19]. Notably, CD147 and CD44 did not account for all MCT1 or MCT4 positive tumors, suggesting the existence of an additional MCT chaperone, as already advocated by other study [20].

As vastly described, the metabolic reprograming of cancer cells is also involved in cancer cell aggressiveness and therapeutic resistance, rendering patients a poor prognosis [10]. The prognostic value of the metabolismrelated proteins evaluated in the present study has been studied in a variety of tumor types; however, only GLUT1 has been evaluated in adrenocortical carcinoma [21]. In Fenske and colleagues study, GLUT1 was expressed in $33 \%$ of adrenocortical carcinoma samples, which is 
Table 2: Association of plasma membrane expression of MCTs with the clinicopathological parameters in adult adrenocortical carcinomas

\begin{tabular}{|c|c|c|c|c|c|c|c|}
\hline & \multirow[t]{2}{*}{$n$} & \multicolumn{2}{|c|}{ MCT1 } & \multicolumn{2}{|c|}{ MCT2 } & \multicolumn{2}{|c|}{ MCT4 } \\
\hline & & Positive (\%) & $p$ & Positive (\%) & $p$ & Positive (\%) & $p$ \\
\hline Tumour size & & & 0.111 & & 0.003 & & 0.536 \\
\hline$<8 \mathrm{~cm}$ & 18 & $14(77.8)$ & & $17(94.4)$ & & $11(61.1)$ & \\
\hline$\geq 8 \mathrm{~cm}$ & 58 & $33(56.9)$ & & $33(56.9)$ & & $40(69.0)$ & \\
\hline Tumour weight & & & 0.417 & & 0.284 & & 0.781 \\
\hline$<467.2 \mathrm{mg}$ & 30 & $18(60.0)$ & & $21(70.0)$ & & $21(70.0)$ & \\
\hline$\geq 467.2 \mathrm{mg}$ & 30 & $21(70.0)$ & & $17(56.7)$ & & $20(66.7)$ & \\
\hline Weiss score & & & 0.382 & & 0.400 & & 0.881 \\
\hline$<6$ & 33 & $19(57.6)$ & & $20(60.6)$ & & $22(66.7)$ & \\
\hline$\geq 6$ & 40 & $27(67.5)$ & & $28(70.0)$ & & $26(65.0)$ & \\
\hline Nuclear grade & & & 0.304 & & 1.000 & & 0.620 \\
\hline Low & 5 & $2(40.0)$ & & $4(80.0)$ & & $3(60.0)$ & \\
\hline High & 36 & $26(72.2)$ & & $27(75.0)$ & & $26(72.2)$ & \\
\hline Mitotic index & & & 0.790 & & 0.008 & & 0.296 \\
\hline Low & 24 & $16(66.7)$ & & $22(91.7)$ & & $15(62.5)$ & \\
\hline High & 17 & $12(70.6)$ & & $9(52.9)$ & & $14(82.4)$ & \\
\hline Atypical mitosis & & & 0.164 & & 0.241 & & 0.276 \\
\hline Absent & 28 & $17(60.7)$ & & $23(82.1)$ & & $18(64.3)$ & \\
\hline Present & 13 & $11(84.6)$ & & $8(61.5)$ & & $11(84.6)$ & \\
\hline Tissue p53 status & & & 0.118 & & 1.000 & & 0.272 \\
\hline Normal & 19 & $10(52.6)$ & & $10(52.6)$ & & $12(63.2)$ & \\
\hline Mutated & 5 & $5(100.0)$ & & $3(60.0)$ & & $5(100.0)$ & \\
\hline Necrosis & & & 1.000 & & 0.700 & & 0.701 \\
\hline Absent & 11 & $8(72.7)$ & & $9(81.8)$ & & $7(63.6)$ & \\
\hline Present & 30 & $20(66.7)$ & & $22(73.3)$ & & $22(73.3)$ & \\
\hline Venous invasion & & & 0.481 & & 0.064 & & 0.165 \\
\hline Absent & 27 & $17(63.0)$ & & $23(85.2)$ & & $17(63.0)$ & \\
\hline Present & 14 & $11(78.6)$ & & $8(57.1)$ & & $12(85.7)$ & \\
\hline Sinus invasion & & & 0.645 & & 0.024 & & 1.000 \\
\hline Absent & 35 & $23(65.7)$ & & $29(82.9)$ & & $25(71.4)$ & \\
\hline Present & 6 & $5(83.3)$ & & $2(33.3)$ & & $4(66.7)$ & \\
\hline $\begin{array}{l}\text { Capsular } \\
\text { invasion }\end{array}$ & & & 1.000 & & 0.700 & & 1.000 \\
\hline Absent & 27 & $19(70.4)$ & & $21(77.8)$ & & $19(70.4)$ & \\
\hline Present & 13 & $9(69.2)$ & & $9(69.2)$ & & $9(69.2)$ & \\
\hline Staging & & & 0.029 & & 0.186 & & 0.674 \\
\hline
\end{tabular}

(Continued) 


\begin{tabular}{|c|c|c|c|c|c|c|c|}
\hline & \multirow[t]{2}{*}{$n$} & \multicolumn{2}{|c|}{ MCT1 } & \multicolumn{2}{|c|}{ MCT2 } & \multicolumn{2}{|c|}{ MCT4 } \\
\hline & & Positive (\%) & $p$ & Positive (\%) & $p$ & Positive (\%) & $p$ \\
\hline $\mathrm{I}+\mathrm{II}$ & 43 & $22(51.2)$ & & $31(72.1)$ & & $28(65.1)$ & \\
\hline III+IV & 33 & $25(75.8)$ & & $19(57.6)$ & & $23(69.7)$ & \\
\hline Metastasis & & & 0.079 & & 0.022 & & 0.200 \\
\hline Absent & 37 & $19(51.4)$ & & $29(78.4)$ & & $22(59.5)$ & \\
\hline Present & 41 & 29 (70.7) & & $22(53.7)$ & & $30(73.2)$ & \\
\hline
\end{tabular}

Table 3: Association of plasma membrane expression of CD147, CD44, GLUT1 and CAIX with the clinicopathological parameters in adult adrenocortical carcinomas

\begin{tabular}{|c|c|c|c|c|c|c|c|c|c|c|c|}
\hline & \multicolumn{3}{|c|}{ CD147 } & \multicolumn{3}{|c|}{ CD44 } & \multicolumn{3}{|c|}{ GLUT1 } & \multicolumn{2}{|c|}{ CAIX } \\
\hline & $n$ & $\begin{array}{c}\text { Positive } \\
(\%)\end{array}$ & $p$ & $n$ & $\begin{array}{c}\text { Positive } \\
(\%)\end{array}$ & $p$ & $n$ & $\begin{array}{c}\text { Positive } \\
(\%)\end{array}$ & $p$ & $\begin{array}{c}\text { Positive } \\
(\%)\end{array}$ & $p$ \\
\hline Tumour size & & & 0.009 & & & 0.238 & & & 0.299 & & 0.075 \\
\hline$<8 \mathrm{~cm}$ & 18 & $18(100.0)$ & & 18 & $7(38.9)$ & & 18 & $5(27.8)$ & & $5(27.8)$ & \\
\hline$\geq 8 \mathrm{~cm}$ & 58 & $42(72.4)$ & & 57 & $14(24.6)$ & & 58 & $\begin{array}{c}24 \\
(41.4)\end{array}$ & & $30(51.7)$ & \\
\hline Tumour weight & & & 0.347 & & & 0.937 & & & 0.592 & & 1.000 \\
\hline$<467.2 \mathrm{mg}$ & 30 & $25(83.3)$ & & 29 & $8(27.6)$ & & 30 & $\begin{array}{c}10 \\
(33.3)\end{array}$ & & $14(46.7)$ & \\
\hline$\geq 467.2 \mathrm{mg}$ & 30 & $22(73.3)$ & & 30 & $8(26.7)$ & & 30 & $\begin{array}{c}12 \\
(40.0)\end{array}$ & & $14(46.7)$ & \\
\hline Weiss score & & & 0.895 & & & 0.752 & & & 0.958 & & 0.969 \\
\hline$<6$ & 33 & $26(78.8)$ & & 33 & $8(24.2)$ & & 33 & $\begin{array}{c}13 \\
(39.4)\end{array}$ & & $15(45.5)$ & \\
\hline$\geq 6$ & 40 & $31(77.5)$ & & 40 & $11(27.5)$ & & 40 & $\begin{array}{c}16 \\
(40.0)\end{array}$ & & $18(45.0)$ & \\
\hline Nuclear grade & & & 1.000 & & & 0.645 & & & 0.382 & & 0.048 \\
\hline Low & 5 & $5(100.0)$ & & 5 & $1(20.0)$ & & 5 & $1(20.0)$ & & $0(0.0)$ & \\
\hline High & 36 & 35 (97.2) & & 36 & $13(36.1)$ & & 36 & $\begin{array}{c}16 \\
(44.4)\end{array}$ & & $20(55.6)$ & \\
\hline Mitotic index & & & 1.000 & & & 0.591 & & & 0.011 & & 0.279 \\
\hline Low & 24 & $23(95.8)$ & & 24 & $9(37.5)$ & & 24 & $6(25.0)$ & & $10(41.7)$ & \\
\hline High & 17 & $17(100.0)$ & & 17 & $5(29.4)$ & & 17 & $\begin{array}{c}11 \\
(64.7)\end{array}$ & & $10(58.8)$ & \\
\hline Atypical mitosis & & & 1.000 & & & 0.734 & & & 0.075 & & 0.265 \\
\hline Absent & 28 & $27(96.4)$ & & 28 & $9(32.1)$ & & 28 & $9(32.1)$ & & $12(42.9)$ & \\
\hline Present & 13 & $13(100.0)$ & & 13 & $5(38.5)$ & & 13 & $8(61.5)$ & & $8(61.5)$ & \\
\hline Tissue p53 status & & & 0.272 & & & 1.000 & & & 0.122 & & 0.317 \\
\hline Normal & 19 & $12(63.2)$ & & 19 & $3(15.8)$ & & 19 & $6(31.6)$ & & $8(42.1)$ & \\
\hline Mutated & 5 & $5(100.0)$ & & 5 & $1(20.0)$ & & 5 & $4(80.0)$ & & $4(80.0)$ & \\
\hline Necrosis & & & 0.268 & & & 0.140 & & & 0.736 & & 0.335 \\
\hline
\end{tabular}

(Continued) 


\begin{tabular}{|c|c|c|c|c|c|c|c|c|c|c|c|}
\hline & \multicolumn{3}{|c|}{ CD147 } & \multicolumn{3}{|c|}{ CD44 } & & \multicolumn{2}{|c|}{ GLUT1 } & \multicolumn{2}{|c|}{ CAIX } \\
\hline & $n$ & $\begin{array}{c}\text { Positive } \\
\text { (\%) }\end{array}$ & $p$ & $n$ & $\begin{array}{c}\text { Positive } \\
\text { (\%) }\end{array}$ & $p$ & $n$ & $\begin{array}{c}\text { Positive } \\
\text { (\%) }\end{array}$ & $p$ & $\begin{array}{c}\text { Positive } \\
\text { (\%) }\end{array}$ & $p$ \\
\hline Absent & 11 & $10(90.9)$ & & 11 & $6(54.5)$ & & 11 & $4(36.4)$ & & $4(36.4)$ & \\
\hline Present & 30 & $30(100.0)$ & & 30 & $8(26.7)$ & & 30 & $\begin{array}{c}13 \\
(43.3)\end{array}$ & & $16(53.3)$ & \\
\hline Venous invasion & & & 1.000 & & & 1.000 & & & 0.424 & & 0.153 \\
\hline Absent & 27 & $26(96.3)$ & & 27 & $9(33.3)$ & & 27 & $\begin{array}{c}10 \\
(37.0)\end{array}$ & & $11(40.7)$ & \\
\hline Present & 14 & $14(100.0)$ & & 14 & $5(35.7)$ & & 14 & $7(50.0)$ & & $9(64.3)$ & \\
\hline Sinus invasion & & & 1.000 & & & 0.645 & & & 0.066 & & 1.000 \\
\hline Absent & 35 & 34 (97.1) & & 35 & $13(37.1)$ & & 35 & $\begin{array}{c}12 \\
(34.3)\end{array}$ & & $17(48.6)$ & \\
\hline Present & 6 & $6(100.0)$ & & 6 & $1(16.7)$ & & 6 & $5(83.3)$ & & $3(50.0)$ & \\
\hline $\begin{array}{l}\text { Capsular } \\
\text { invasion }\end{array}$ & & & 1.000 & & & 1.000 & & & 0.581 & & 0.311 \\
\hline Absent & 27 & $26(96.3)$ & & 27 & $9(33.3)$ & & 27 & $\begin{array}{c}10 \\
(37.0)\end{array}$ & & $12(44.4)$ & \\
\hline Present & 13 & $13(100.0)$ & & 13 & $5(38.5)$ & & 13 & $6(46.2)$ & & $8(61.5)$ & \\
\hline Staging & & & 0.550 & & & 0.521 & & & 0.251 & & 0.193 \\
\hline $\mathrm{I}+\mathrm{II}$ & 43 & $35(81.4)$ & & 42 & $13(31.0)$ & & 43 & $\begin{array}{c}14 \\
(32.6)\end{array}$ & & $17(39.5)$ & \\
\hline $\mathrm{III}+\mathrm{IV}$ & 33 & $25(75.8)$ & & 33 & $8(24.2)$ & & 33 & $\begin{array}{c}15 \\
(45.5)\end{array}$ & & $18(54.5)$ & \\
\hline Metastasis & & & 0.559 & & & 0.263 & & & 0.004 & & 0.021 \\
\hline Absent & 37 & $30(81.1)$ & & 36 & $12(33.3)$ & & 37 & $8(21.6)$ & & $12(32.4)$ & \\
\hline Present & 41 & $31(75.6)$ & & 41 & $9(22.0)$ & & 41 & $\begin{array}{c}22 \\
(53.7)\end{array}$ & & $24(58.5)$ & \\
\hline
\end{tabular}

similar to the expression frequency found in the present study [21]. Herein, we show associations between GLUT1 and high mitotic index, presence of metastasis, and both longer overall and disease-free survival. This evidence is in agreement with the crucial role of GLUT1 in the metabolic reprogramming, as cancer cells are only able to depend on glycolytic pathway for energy production if the glycolytic flow is highly increased. This demands an increased uptake of glucose, mainly provided by GLUT1 in cancer cells [29].

MCT1 expression at the plasma membrane suggests a high lactate efflux from cancer cells, which, besides allowing glycolytic flux for energy production, also detains an important role in the microenvironment, by decreasing the immune response against tumor cells [30], increasing tumor cell motility [31], inducing angiogenesis [32], as well as stimulating hyaluronan and its receptor CD44, molecules involved in the process of cancer invasion and metastasis [33]. These roles of lactate in the extracellular milieu are in accordance with the association of MCT1 expression with high stage and shorter overall survival. In opposition, plasma membrane expression of MCT4, which was increased from adenomas to carcinomas, showed no association with the clinicopathological parameters. However, cytoplasmic expression of MCT4, as well as CD147, was associated with absence of metastasis. In accordance, cytoplasmic expression of MCT4 and CD147 was also associated with longer disease-free survival, while cytoplasmic expression of CD147 also showed a tendency to be associated with longer overall survival. Further studies are warranted to elucidate the role of MCT4 in the cytoplasm. Importantly, MCT2 plasma membrane expression was associated with good 

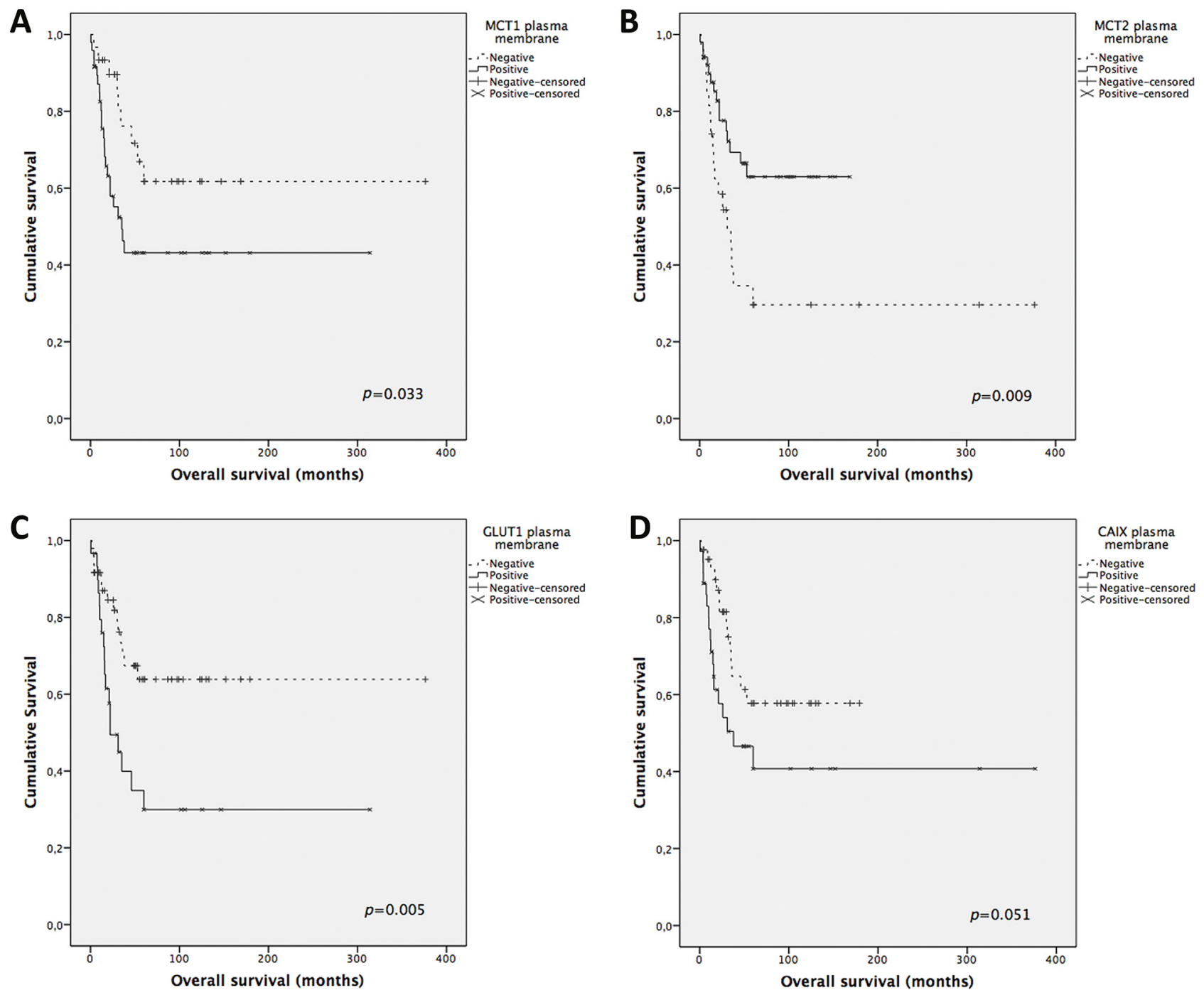

Figure 3: Overall survival curves of adrenocortical carcinomas' patients. The results are stratified according to protein immunohistochemical expression. Only significant (or borderline) results are shown. Continuous line refers to positive expression while interrupted line refers to negative expression. A. Plasma membrane expression of MCT1; B. Plasma membrane expression of MCT2; C. Plasma membrane expression of GLUT1; D. Plasma membrane expression of CAIX.

prognostic variables, including small tumor size, low mitotic index, absence of sinus invasion, absence of metastasis and longer overall survival. MCT2 expression at the plasma membrane suggests monocarboxylate consumption (likely lactate) from the extracellular environment. Since MCT2 plasma membrane expression is independent from MCT1 or MCT4 (data not shown), MCT2 positive tumors may present a metabolic symbiosis between cancer cells, in which the peripheral and oxygenated oxidative cells consume, through MCT2, the lactate released, through MCT4, by the central and less oxygenated glycolytic cells [34]. As a result, lactate will no longer act in the microenvironment to stimulate tumor aggressiveness. This rationale is in line with the evidence that MCT2 expressing tumors show a less aggressive phenotype than MCT2 negative tumors. Finally, we found CAIX to be more frequently expressed at the plasma membrane of tumors showing high nuclear grade and presence of metastasis, which is in accordance with the contribution of CAIX to the acid-resistant phenotype, rendering cancer cells a survival advantage that will contribute to cancer progression. Also, since CAIX contributes to the extracellular acidification, this $\mathrm{pH}$ regulator has a role in the acid-mediated cancer cell invasive behavior [35].

In line with the role of the different proteins in the metabolic remodeling of cancer cells and the evidence from the associations with the clinicopathological data, plasma membrane expression of MCT1 or GLUT1 was identified as a poor prognostic factor and plasma 

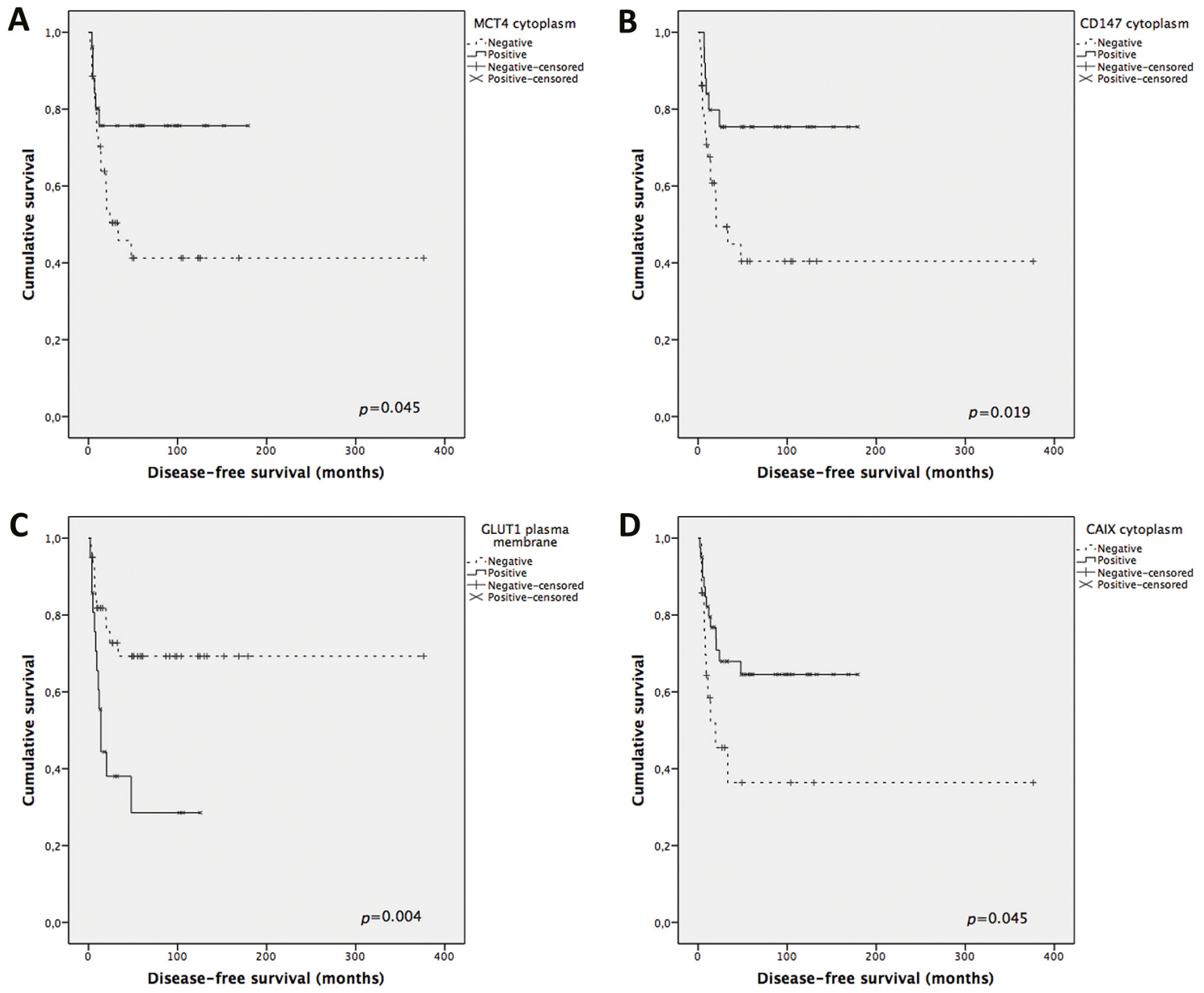

Figure 4: Disease-free survival curves of adrenocortical carcinomas' patients. The results are stratified according to protein immunohistochemical expression. Only significant results are shown. Continuous line refers to positive expression while interrupted line refers to negative expression. A. Cytoplasmic expression of MCT4; B. Cytoplasmic expression of CD147; C. Plasma membrane expression of GLUT1; D. Cytoplasmic expression of CAIX.

membrane expression of MCT2 was identified as a good prognostic factor for overall survival in univariate analysis. Multivariate analysis showed that none of these markers has a stage-independent prognostic value, differently from results previously described for GLUT1 [21]. Importantly, CD147 cytoplasmic expression was identified as a stage-independent good prognostic factor for overall survival. In disease-free survival, while plasma membrane of GLUT1 was identified as a poor prognostic factor and plasma membrane expression of MCT2 and cytoplasmic expression of CD147 were identified as good prognostic value in univariate analysis, multivariate analysis showed that none of these markers has a stage-independent prognostic value. Importantly, CAIX cytoplasmic expression, while showing borderline significance in the univariate analysis, was identified as a stage-independent good prognostic factor for diseasefree survival.

In the present study, we provided evidence for a metabolic reprogramming of adrenocortical malignant tumors towards the hyperglycolytic and acid-resistant phenotype characteristic of the Warburg effect, which associates with a worse prognosis. Since only few studies are available on the metabolic reprogramming of adult adrenocortical carcinoma, we believe that the results from the present study may bring new and relevant knowledge about the biology of this rare type of cancer, with possible developments in adrenocortical carcinoma management and the search for new target-directed therapeutic resources. 
Table 4: Prognostic factors for overall survival and disease-free survival in adult adrenocortical carcinomas

\begin{tabular}{|c|c|c|c|c|c|c|}
\hline & \multicolumn{3}{|c|}{ Univariate analysis } & \multicolumn{3}{|c|}{ Multivariate analysis } \\
\hline & \multicolumn{6}{|c|}{ Overall survival } \\
\hline & HR & $95 \% \mathrm{CI}$ & $p$ & HR & $95 \% \mathrm{CI}$ & $p$ \\
\hline Male sex & 0.73 & $0.28-1.87$ & 0.51 & & & \\
\hline Age (yrs) & 0.99 & $0.98-1.02$ & 0.76 & & & \\
\hline Tumor size $\geq 8 \mathrm{~cm}$ & 3.86 & $1.37-10.9$ & 0.01 & 3.6 & $0.7-17.5$ & 0.13 \\
\hline Weiss score $\geq 6$ & 0.86 & $0.44-1.67$ & 0.64 & & & \\
\hline Tumor stage (ENSAT 3) & 5.1 & $2.4-10.8$ & 0.0001 & 2.3 & $1.5-8.8$ & 0.005 \\
\hline MCT1 cytoplasm & 1.05 & $0.47-2.3$ & 0.91 & & & \\
\hline MCT1 plasma membrane & 2.27 & $1.04-4.91$ & 0.038 & 2.3 & $0.91-5.7$ & 0.077 \\
\hline MCT2 cytoplasm & 0.83 & $0.41-1.67$ & 0.6 & & & \\
\hline MCT2 plasma membrane & 0.409 & $0.20-0.82$ & 0.01 & 0.78 & $0.34-0.74$ & 0.548 \\
\hline MCT4 cytoplasm & 0.53 & $0.24-1.14$ & 0.1 & & & \\
\hline MCT4 plasma membrane & 1.59 & $0.71-3.55$ & 0.26 & & & \\
\hline CD147 cytoplasm & 0.49 & $0.232-1.04$ & 0.063 & 0.32 & $0.14-0.74$ & 0.008 \\
\hline CD147 plasma membrane & 0.94 & $0.44-2.05$ & 0.89 & & & \\
\hline CD44 cytoplasm & 0.63 & $0.2-1.8$ & 0.39 & & & \\
\hline CD44 plasma membrane & 0.9 & $0.4-2.0$ & 0.79 & & & \\
\hline GLUT1 cytoplasm & 1.3 & $0.6-2.81$ & 0.5 & & & \\
\hline GLUT1 plasma membrane & 2.63 & $1.3-5.3$ & 0.007 & 1.97 & $0.9-4.2$ & 0.088 \\
\hline CAIX cytoplasm & 0.545 & $0.27-1.1$ & 0.092 & 0.72 & $0.32-1.62$ & 0.43 \\
\hline \multirow[t]{3}{*}{ CAIX plasma membrane } & 1.98 & $0.98-3.99$ & 0.056 & 0.96 & $0.42-2.18$ & 0.93 \\
\hline & \multicolumn{6}{|c|}{ Disease-free survival } \\
\hline & HR & $95 \% \mathrm{CI}$ & $p$ & HR & $95 \% \mathrm{CI}$ & $\boldsymbol{P}$ \\
\hline Male sex & 1.1 & $0.45-2.8$ & 0.81 & & & \\
\hline Age (yrs) & 1.06 & $0.98-1.03$ & 0.63 & & & \\
\hline Tumor size $8 \geq \mathrm{cm}$ & 3.49 & $1.2-10.4$ & 0.022 & 1.76 & $0.45-6.8$ & 0.41 \\
\hline Weiss score $\geq 6$ & 0.695 & $0.33-1.46$ & 0.33 & & & \\
\hline Tumor stage (ENSAT 3) & 4.46 & $2.1-9.5$ & 0.0001 & 3.96 & $1.4-10.9$ & 0.008 \\
\hline MCT1 cytoplasm & 1.44 & $0.58-3.53$ & 0.43 & & & \\
\hline MCT1 plasma membrane & 2.1 & $0.84-5.1$ & 0.11 & & & \\
\hline MCT2 cytoplasm & 1.32 & $0.56-3.1$ & 0.52 & & & \\
\hline MCT2 plasma membrane & 0.42 & $0.18-0.97$ & 0.04 & 0.74 & $0.28-1.9$ & 0.527 \\
\hline MCT4 cytoplasm & 0.42 & $0.16-1.08$ & 0.071 & 1.12 & $0.36-3.5$ & 0.843 \\
\hline MCT4 plasma membrane & 1.22 & $0.497-2.99$ & 0.66 & & & \\
\hline CD147 cytoplasm & 0.36 & $0.14-0.92$ & $\mathbf{0 . 0 3 3}$ & 0.43 & $0.16-1.18$ & 0.1 \\
\hline
\end{tabular}

(Continued) 


\begin{tabular}{|c|c|c|c|c|c|c|}
\hline & \multicolumn{3}{|c|}{ Univariate analysis } & \multicolumn{3}{|c|}{ Multivariate analysis } \\
\hline & \multicolumn{6}{|c|}{ Overall survival } \\
\hline & HR & $95 \% \mathrm{CI}$ & $p$ & HR & $95 \% \mathrm{CI}$ & $p$ \\
\hline CD147 plasma membrane & 1.02 & $0.37-2.76$ & 0.97 & & & \\
\hline CD44 cytoplasm & 0.23 & $0.03-1.85$ & 0.17 & & & \\
\hline CD44 plasma membrane & 0.99 & $0.35-2.77$ & 0.98 & & & \\
\hline GLUT1 cytoplasm & 0.55 & $0.18-1.61$ & 0.27 & & & \\
\hline GLUT1 plasma membrane & 3.84 & $1.52-9.68$ & 0.004 & 2.4 & $0.86-6.74$ & 0.097 \\
\hline CAIX cytoplasm & 0.47 & $0.2-1.1$ & 0.079 & 0.31 & $0.1-0.92$ & 0.036 \\
\hline CAIX plasma membrane & 1.95 & $0.84-4.53$ & 0.12 & & & \\
\hline
\end{tabular}

A

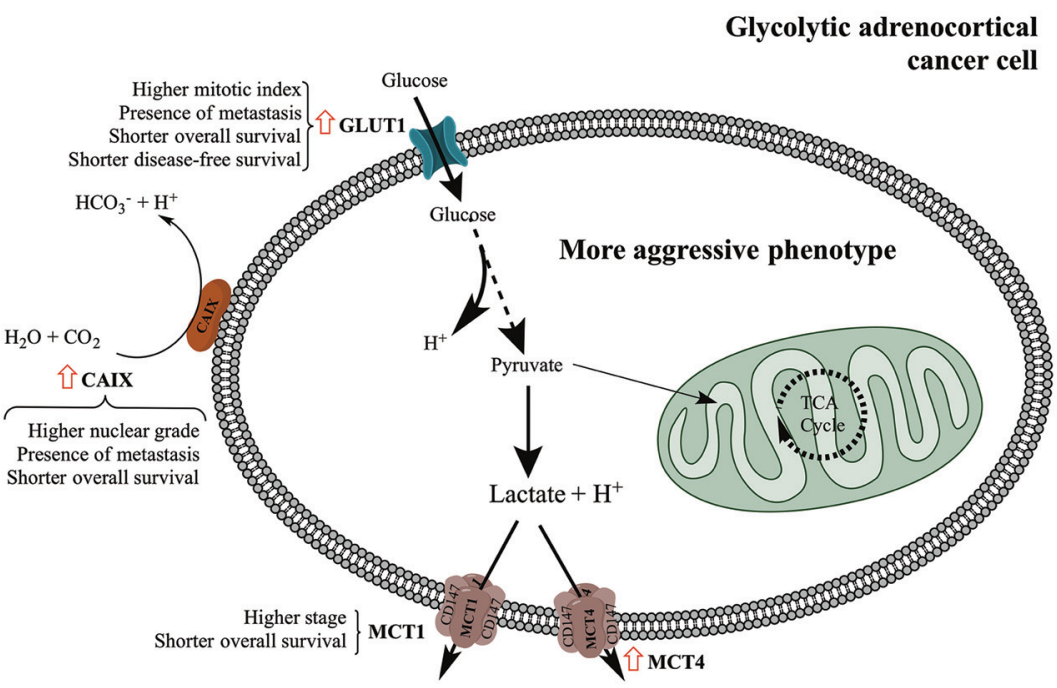

Lactate $+\mathrm{H}^{+}$

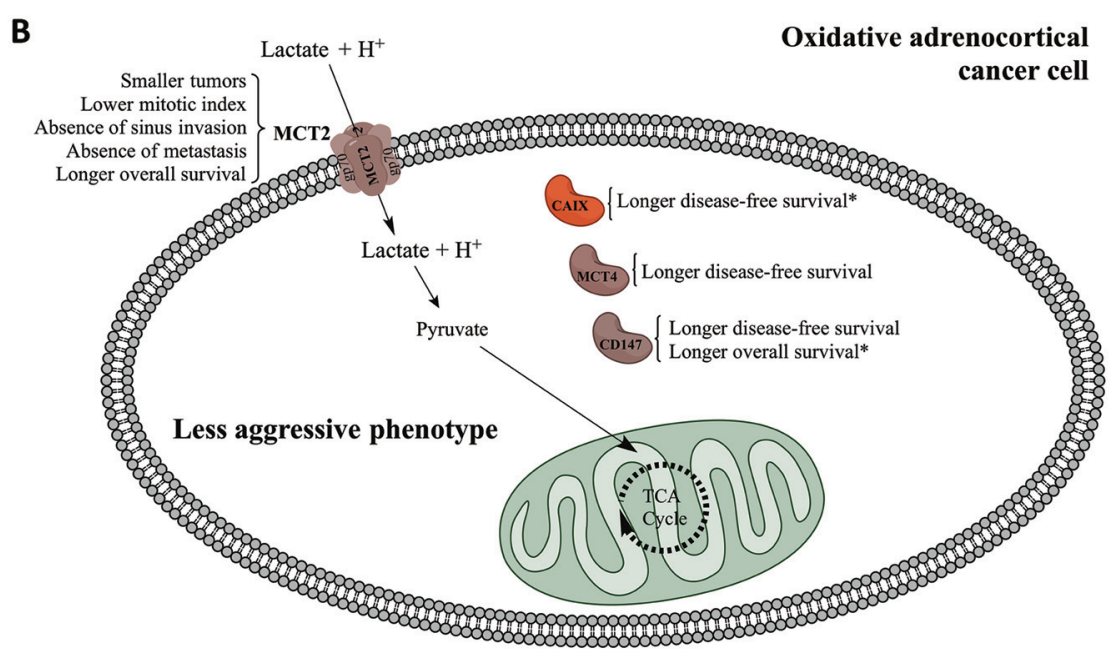

Figure 5: Schematic representation summarizing the major findings of the present work. The schematic representation distinguishes the major findings for plasma membrane and cytoplasmic expression of the different proteins studied. Red arrow: significant increase in expression frequency when comparing adenomas to carcinomas. * Independent predictors of survival as determined by multivariate analysis. 


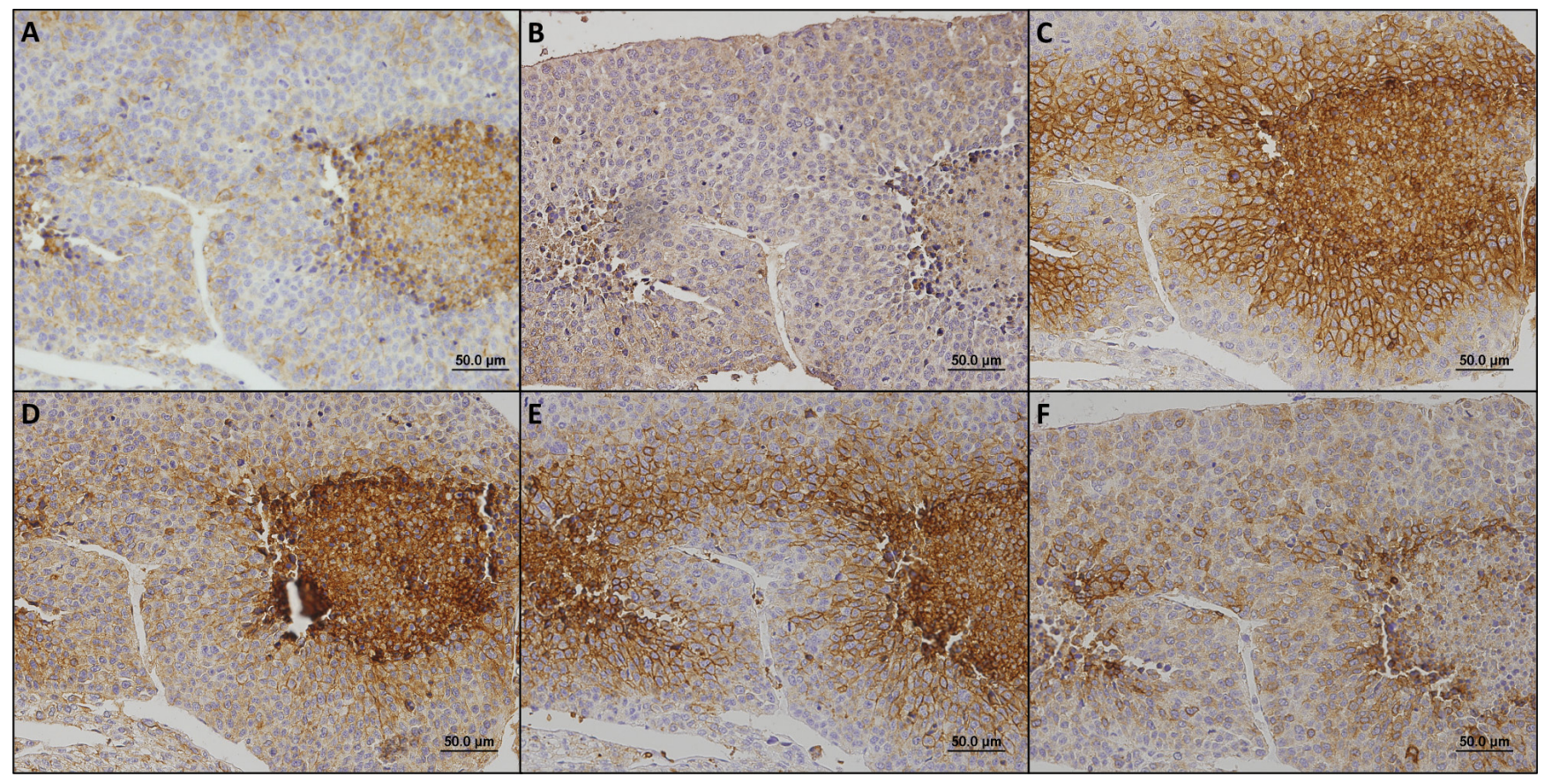

Figure 6: Immunohistochemical staining patterns of metabolism-related proteins in a case representative of the glycolytic phenotype. In this case, MCT1 A. MCT4 C. CD147 D. GLUT1 E. and CAIX F. were found in the plasma membrane while MCT2 B. was observed in the cytoplasm.

\section{MATERIALS AND METHODS}

\section{Human adrenocortical tumor samples}

The series analyzed included 154 formalinfixed paraffin-embedded adrenocortical neoplasias (76 adenomas and 78 carcinomas, according to Weiss score), retrieved from the files of the Pathology Department of the Clinical Hospital, School of Medicine, University of Sao Paulo, Brazil. No case included in this series fulfills the criteria for oncocytic tumor. Samples were organized into tissue microarrays (TMA) containing 208 cores each $(1.0 \mathrm{~mm}$ diameter each core). Each case was represented in TMAs by three cores and control samples (kidney) were also included for TMA orientation. Clinicopathological data for the adrenocortical carcinomas included age at diagnosis (normal distribution, mean 40.6 years, range: 15 to 81 years), gender, tumor size (normal distribution, mean $11.8 \mathrm{~cm}$, range: 2.2 to $23.0 \mathrm{~cm}$; categorized using $8 \mathrm{~cm}$ as cut-off [36]) and weight (non-normal distribution, median $467.2 \mathrm{mg}$, range: 10 to $2600 \mathrm{mg}$ ), Weiss score and each of its individual histological parameters [37], tumor p53 status, staging (according to ENSAT system [38]), metastasis, disease-free survival and overall survival (median 13.5 and 30.5 months, respectively). Cases that could not be evaluated by Weiss score were classified as carcinomas if metastatic disease was detected (clinically malignant). Detailed information of the clinicopathological data for the adrenocortical adenomas as well as the adrenocortical carcinomas is presented in Tables 5 and 6 , respectively. The present study was approved by the Local Ethic Committee (number 11090).

\section{Immunohistochemistry}

MCT1 immunohistochemistry was performed according to the avidin-biotin-peroxidase complex method (R.T.U. VECTASTAIN Elite ABC Kit (Universal), Vector Laboratories, Burlingame, CA), as previously described [39]. Immunohistochemistry for MCT2, MCT4, GLUT1, CD44 and CAIX was performed according to the streptavidin-biotin-peroxidase complex principle (Ultravision Detection System Anti-polyvalent, HRP, Lab Vision Corporation, Fremont, CA), as previously described [20, 40, 41]. CD147 immunostaining was performed using a polymer system (UltraVision ONE Detection System: HRP Polymer Lab Vision Corporation, Fremont, CA) as already described [42]. Negative controls were performed by the use of appropriate serum controls for the primary antibodies (N1698 and N1699, Dako, Carpinteria, CA). Colon carcinoma tissue was used as positive control for MCT1, MCT4, CD147 and CD44, head and neck squamous cell carcinoma was used for GLUT1, and normal stomach was used for CAIX. Tissue sections were counterstained with hematoxylin and permanently mounted. Please refer to Table 7 for detailed aspects for each antibody used. 


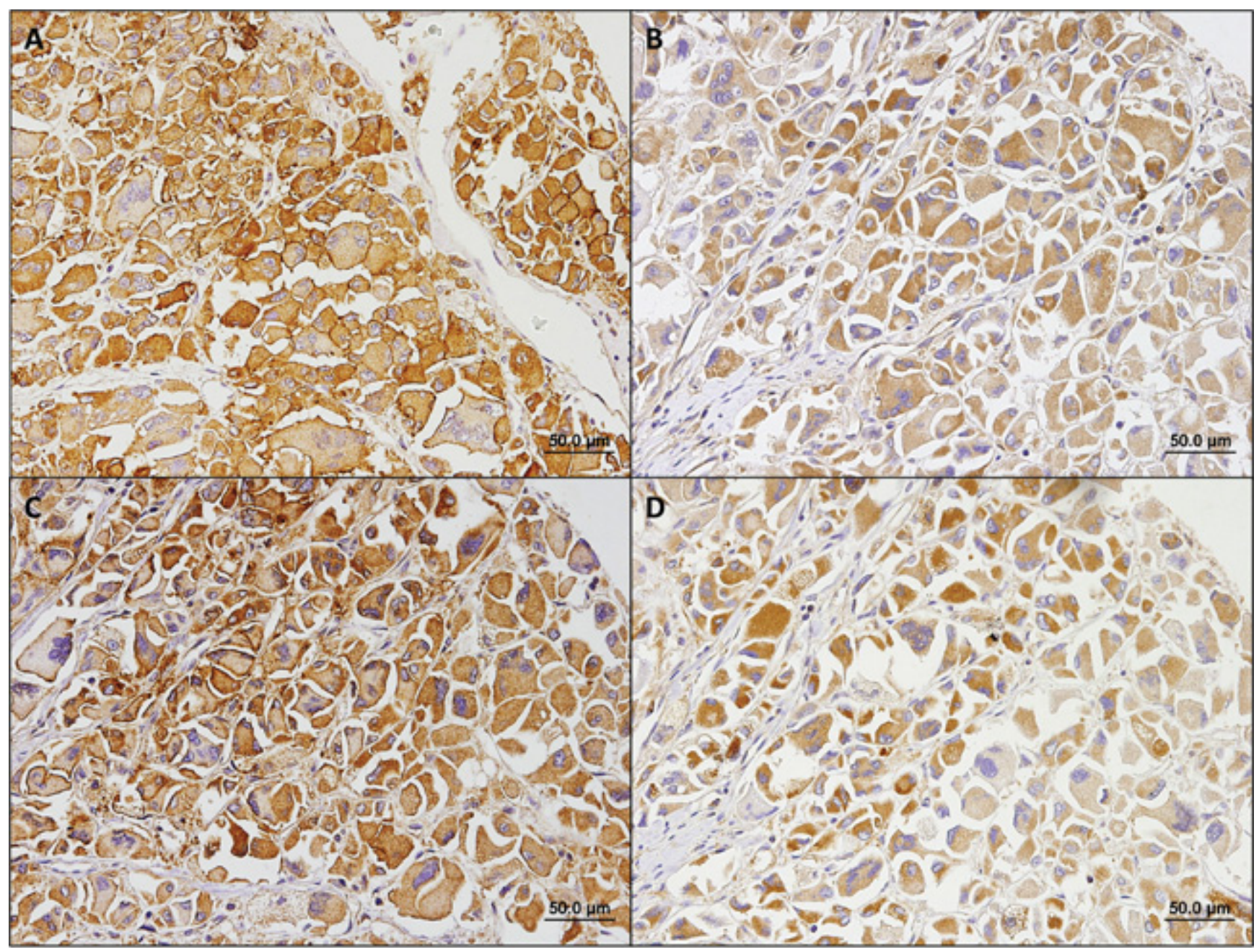

Figure 7: Immunohistochemical staining patterns of metabolism-related proteins in a case representative of the oxidative phenotype. In this case, MCT2 A. was found in the plasma membrane, while MCT4 B. CD147 C. and CAIX D. were found in the cytoplasm.

\section{Immunohistochemical evaluation}

Sections were scored semi-quantitatively for expression in cancer cells as follows: 0: no immunoreactive cells; $1:<5 \%$ of immunoreactive cells; $2: 5-50 \%$ of immunoreactive cells; and 3: $>50 \%$ of immunoreactive cells. Also, intensity of staining was scored semi-qualitatively as follows: 0 : negative; 1 : weak; 2 : intermediate; and 3 : strong. The final score was defined as the sum of both parameters (extension and intensity), and, for the metabolism-related proteins, grouped as negative (score 0 and 2) and positive (score 3-6), as previously described [39]. Protein expression in the different cellular localizations (cytoplasm and plasma membrane) was evaluated separately.

\section{Statistical analysis}

Data were stored and analyzed using the IBM SPSS Statistics software (version 20, IBM Company,
Armonk, NY). All comparisons were examined for statistical significance using Pearson's chi-square $\left(\chi^{2}\right)$ test and Fisher's exact test (when $n<5$ ). Overall survival was defined as the time from the date of primary diagnosis to death related to adrenocortical cancer or last follow-up. Disease-free survival was defined as the time from the date of complete tumor resection to the first radiological evidence of disease relapse or death. Overall and diseasefree survival curves were estimated by the method of Kaplan-Meier and data compared using the log-rank test. Predictive factors of prognosis were identified by means of Cox proportional hazards regression models, which were used to estimate hazard ratios (HR) and their $95 \%$ confidence intervals in univariate and multivariate analysis. All variables that reached a $p$ value $<0.1$ at Kaplan-Meier estimates were included in the Cox survival analysis. For multivariate analysis, variables that reached a $p$ value $<0.1$ at univariate analysis were included. The threshold for significant $p$ values was established as $p<0.05$. 
Table 5: Clinicopathological data of the adrenocortical adenoma patients

\begin{tabular}{|c|c|c|}
\hline Variable & $n$ & $\%$ \\
\hline \multicolumn{3}{|l|}{$\operatorname{Age}^{\#}(n=76)$} \\
\hline$\geq 44.2$ years & 35 & 46.1 \\
\hline$<44.2$ years & 41 & 53.9 \\
\hline \multicolumn{3}{|c|}{ Gender $(n=76)$} \\
\hline Female & 66 & 86.8 \\
\hline Male & 10 & 13.2 \\
\hline \multicolumn{3}{|c|}{ Tumor size $(n=73)$} \\
\hline$<8 \mathrm{~cm}$ & 71 & 97.3 \\
\hline$\geq 8 \mathrm{~cm}$ & 2 & 2.7 \\
\hline \multicolumn{3}{|c|}{ Tumor weight $(n=64)$} \\
\hline$<20.0 \mathrm{mg}$ & 29 & 45.3 \\
\hline$\geq 20.0 \mathrm{mg}$ & 35 & 54.7 \\
\hline \multicolumn{3}{|c|}{ Weiss score $(n=76)$} \\
\hline 0 & 35 & 46.1 \\
\hline 1 & 22 & 28.9 \\
\hline 2 & 19 & 25.0 \\
\hline \multicolumn{3}{|c|}{ Nuclear grade* $(n=42)$} \\
\hline Low & 37 & 88.1 \\
\hline High & 5 & 11.9 \\
\hline \multicolumn{3}{|c|}{ Mitotic índex* $(n=42)$} \\
\hline Low & 41 & 97.6 \\
\hline High & 1 & 2.4 \\
\hline \multicolumn{3}{|c|}{ Atypical mitosis $(n=42)$} \\
\hline Absent & 42 & 100.0 \\
\hline Present & $\mathbf{0}$ & 0.0 \\
\hline \multicolumn{3}{|c|}{ Necrosis $(n=42)$} \\
\hline Absent & 38 & 90.5 \\
\hline Present & 4 & 9.5 \\
\hline \multicolumn{3}{|c|}{ Venous invasion $(n=42)$} \\
\hline Absent & 42 & 100.0 \\
\hline Present & $\mathbf{0}$ & 0.0 \\
\hline \multicolumn{3}{|c|}{ Sinus invasion $(n=42)$} \\
\hline Absent & 41 & 97.6 \\
\hline Present & 1 & 2.4 \\
\hline \multicolumn{3}{|c|}{ Capsular invasion $(n=41)$} \\
\hline Absent & 38 & 92.7 \\
\hline Present & 3 & 7.3 \\
\hline
\end{tabular}




\begin{tabular}{l}
\hline Variable \\
\begin{tabular}{|l|c|c|}
\hline Staging $(\boldsymbol{n}=\mathbf{5 6})$ & $n$ & $\%$ \\
\hline I & 49 & 87.5 \\
\hline II & 7 & 12.5 \\
\hline
\end{tabular}
\end{tabular}

\#The mean value was used for age cut-off, while the median value was used for weight cut-off as these variables followed a normal and non-normal distribution, respectively.

${ }^{*}$ Nuclear grade and mitotic index were defined according to Weiss score definitions (30).

Table 6: Clinicopathological data of the adrenocortical carcinoma patients

\begin{tabular}{|c|c|c|}
\hline Variable & $n$ & $\%$ \\
\hline \multicolumn{3}{|l|}{$\operatorname{Age}^{\#}(n=78)$} \\
\hline$\geq 40.6$ years & 34 & 43.6 \\
\hline$<40.6$ years & 44 & 56.4 \\
\hline \multicolumn{3}{|c|}{ Gender $(n=78)$} \\
\hline Female & 61 & 78.2 \\
\hline Male & 17 & 21.8 \\
\hline \multicolumn{3}{|c|}{ Tumor size $(n=76)$} \\
\hline$<8 \mathrm{~cm}$ & 18 & 23.7 \\
\hline$\geq 8 \mathrm{~cm}$ & 58 & 76.3 \\
\hline \multicolumn{3}{|c|}{ Tumor weight $(n=60)$} \\
\hline$<467.2 \mathrm{mg}$ & 30 & 50.0 \\
\hline$\geq 467.2 \mathrm{mg}$ & 30 & 50.0 \\
\hline \multicolumn{3}{|c|}{ Weiss score $(n=78)$} \\
\hline$\geq 3^{\$}$ & 5 & 6.4 \\
\hline 3 & 13 & 16.7 \\
\hline 4 & 13 & 16.7 \\
\hline 5 & 7 & 9.0 \\
\hline 6 & 11 & 14.1 \\
\hline 7 & 11 & 14.1 \\
\hline 8 & 14 & 17.9 \\
\hline 9 & 4 & 5.1 \\
\hline \multicolumn{3}{|c|}{ Nuclear grade* $(n=41)$} \\
\hline Low & 5 & 12.2 \\
\hline High & 36 & 87.8 \\
\hline \multicolumn{3}{|c|}{ Mitotic índex* $(n=41)$} \\
\hline Low & 24 & 58.5 \\
\hline High & 17 & 41.5 \\
\hline \multicolumn{3}{|c|}{ Atypical mitosis $(n=41)$} \\
\hline Absent & 28 & 68.3 \\
\hline Present & 13 & 31.7 \\
\hline
\end{tabular}




\begin{tabular}{|c|c|c|}
\hline Variable & $n$ & $\%$ \\
\hline \multicolumn{3}{|c|}{ Necrosis $(n=41)$} \\
\hline Absent & 11 & 26.8 \\
\hline Present & 30 & 73.2 \\
\hline \multicolumn{3}{|c|}{ Venous invasion $(n=41)$} \\
\hline Absent & 27 & 65.9 \\
\hline Present & 14 & 34.1 \\
\hline \multicolumn{3}{|c|}{ Sinus invasion $(n=41)$} \\
\hline Absent & 35 & 85.4 \\
\hline Present & 6 & 14.6 \\
\hline \multicolumn{3}{|c|}{ Capsular invasion $(n=40)$} \\
\hline Absent & 27 & 67.5 \\
\hline Present & 13 & 32.5 \\
\hline \multicolumn{3}{|c|}{ Staging $(n=76)$} \\
\hline I & 7 & 9.2 \\
\hline II & 36 & 47.4 \\
\hline III & 15 & 19.7 \\
\hline IV & 18 & 23.7 \\
\hline \multicolumn{3}{|c|}{ Metastasis $(n=78)$} \\
\hline Absent & 37 & 47.4 \\
\hline Present & 41 & 52.6 \\
\hline \multicolumn{3}{|c|}{ Evolution $(n=78)$} \\
\hline Alive & 46 & 59.0 \\
\hline Dead & 32 & 41.0 \\
\hline
\end{tabular}

\#The mean value was used for age cut-off, while the median value was used for weight cut-off as these variables followed a normal and non-normal distribution, respectively.

${ }^{s}$ Cases classified as carcinoma (Weiss $\geq 3$ ) based on the presence of metastatic disease.

*Nuclear grade and mitotic index were defined according to Weiss score definitions (30).

Table 7: Detailed aspects for each antibody used in immunohistochemistry

\begin{tabular}{|c|c|c|c|}
\hline Protein & Antigen retrieval & Antibody & $\begin{array}{l}\text { Antibody dilution and } \\
\text { incubation time }\end{array}$ \\
\hline MCT1 & $\begin{array}{l}\text { Citrate buffer }(0.01 \mathrm{M}, \\
\mathrm{pH}=6), 98^{\circ} \mathrm{C}, 20^{\prime}\end{array}$ & $\begin{array}{l}\text { AB3538P } \\
\text { Chemicon International }\end{array}$ & 1:200, overnight \\
\hline MCT2 & $\begin{array}{l}\text { Citrate buffer }(0.01 \mathrm{M}, \\
\mathrm{pH}=6), 98^{\circ} \mathrm{C}, 20^{\prime}\end{array}$ & $\begin{array}{l}\text { sc-50322 } \\
\text { Santa Cruz Biotechnology }\end{array}$ & $1: 200,2$ hours \\
\hline MCT4 & $\begin{array}{l}\text { Citrate buffer }(0.01 \mathrm{M}, \\
\mathrm{pH}=6), 98^{\circ} \mathrm{C}, 20^{\prime}\end{array}$ & $\begin{array}{l}\text { sc-50329 } \\
\text { Santa Cruz Biotechnology }\end{array}$ & $1: 500,2$ hours \\
\hline CD147 & $\begin{array}{l}\text { EDTA }(1 \mathrm{mM}, \mathrm{pH}=8) \\
98^{\circ} \mathrm{C}, 20^{\prime}\end{array}$ & $\begin{array}{l}\text { sc-71038 } \\
\text { Santa Cruz Biotechnology }\end{array}$ & 1:400, overnight \\
\hline
\end{tabular}

(Continued) 


\begin{tabular}{|l|l|l|c|}
\hline \multicolumn{2}{l}{ Protein } & \multicolumn{1}{l}{ Antigen retrieval } & \multicolumn{1}{c}{$\begin{array}{c}\text { Antibody dilution and } \\
\text { incubation time }\end{array}$} \\
\hline CD44 & $\begin{array}{l}\text { Citrate buffer }(0.01 \mathrm{M}, \\
\mathrm{pH}=6), 98^{\circ} \mathrm{C}, 20^{\prime}\end{array}$ & $\begin{array}{l}\text { MCA2726 } \\
\text { AbD Serotec }\end{array}$ & $1: 2000,2$ hours \\
\hline GLUT1 & $\begin{array}{l}\text { Citrate buffer }(0.01 \mathrm{M}, \\
\mathrm{pH}=6), 98^{\circ} \mathrm{C}, 20^{\prime}\end{array}$ & $\begin{array}{l}\text { ab15309-500 } \\
\text { AbCam }\end{array}$ & $1: 500,2$ hours \\
\hline CAIX & $\begin{array}{l}\text { Citrate buffer }(0.01 \mathrm{M}, \\
\mathrm{pH}=6), 98^{\circ} \mathrm{C}, 20^{\prime}\end{array}$ & $\begin{array}{l}\text { ab15086 } \\
\text { AbCam }\end{array}$ & $1: 2000,2$ hours \\
\hline
\end{tabular}

\section{FUNDING}

This work was supported by FAPESP to Maria Claudia Nogueira Zerbini (2013-26344-8). SG received the post-doctoral fellowship UMINHO/BPD/18/2014.

\section{CONFLICTS OF INTEREST}

The authors declare no conflicts of interest.

\section{REFERENCES}

1. Fassnacht M, Libe R, Kroiss M, Allolio B. Adrenocortical carcinoma: a clinician's update. Nat Rev Endocrinol. 2011; 7:323-335.

2. Fassnacht M, Kroiss M, Allolio B. Update in adrenocortical carcinoma. J Clin Endocrinol Metab. 2013; 98:4551-4564.

3. Else T, Kim AC, Sabolch A, Raymond VM, Kandathil A, Caoili EM, Jolly S, Miller BS, Giordano TJ, Hammer GD. Adrenocortical carcinoma. Endocr Rev. 2014; 35:282-326.

4. Fassnacht M, Terzolo M, Allolio B, Baudin E, Haak H, Berruti A, Welin S, Schade-Brittinger C, Lacroix A, Jarzab B, Sorbye H, Torpy DJ, Stepan V, Schteingart DE, Arlt W, Kroiss M, et al. Combination chemotherapy in advanced adrenocortical carcinoma. N Engl J Med. 2012; 366:2189-2197.

5. Berruti A, Baudin E, Gelderblom H, Haak HR, Porpiglia F, Fassnacht M, Pentheroudakis G, Group EGW. Adrenal cancer: ESMO Clinical Practice Guidelines for diagnosis, treatment and follow-up. Ann Oncol. 2012; 23: vii131-138.

6. Faria AM, Almeida MQ. Differences in the molecular mechanisms of adrenocortical tumorigenesis between children and adults. Mol Cell Endocrinol. 2012; 351:52-57.

7. Lucon AM, Pereira MA, Mendonca BB, Zerbini MC, Saldanha LB, Arap S. Adrenocortical tumors: results of treatment and study of Weiss's score as a prognostic factor. Rev Hosp Clin Fac Med Sao Paulo. 2002; 57:251-256.

8. Duregon E, Volante M, Giorcelli J, Terzolo M, Lalli E, Papotti M. Diagnostic and prognostic role of steroidogenic factor 1 in adrenocortical carcinoma: a validation study focusing on clinical and pathologic correlates. Hum Pathol. 2013; 44:822-828.

9. Gatenby RA, Gillies RJ. Why do cancers have high aerobic glycolysis? Nat Rev Cancer. 2004; 4:891-899.

10. Tennant DA, Duran RV, Gottlieb E. Targeting metabolic transformation for cancer therapy. Nat Rev Cancer. 2010; 10:267-277.

11. Chiche J, Brahimi-Horn MC, Pouyssegur J. Tumour hypoxia induces a metabolic shift causing acidosis: a common feature in cancer. J Cell Mol Med. 2010; 14:771-794.

12. Pinheiro C, Longatto-Filho A, Azevedo-Silva J, Casal M, Schmitt FC, Baltazar F. Role of monocarboxylate transporters in human cancers: state of the art. J Bioenerg Biomembr. 2012; 44:127-139.

13. de Oliveira AT, Pinheiro C, Longatto-Filho A, Brito MJ, Martinho O, Matos D, Carvalho AL, Vazquez VL, Silva TB, Scapulatempo C, Saad SS, Reis RM, Baltazar F. Co-expression of monocarboxylate transporter 1 (MCT1) and its chaperone (CD147) is associated with low survival in patients with gastrointestinal stromal tumors (GISTs). $\mathrm{J}$ Bioenerg Biomembr. 2012; 44:171-178.

14. Miranda-Goncalves V, Honavar M, Pinheiro C, Martinho O, Pires MM, Pinheiro C, Cordeiro M, Bebiano G, Costa P, Palmeirim I, Reis RM, Baltazar F. Monocarboxylate transporters (MCTs) in gliomas: expression and exploitation as therapeutic targets. Neuro Oncol. 2013; 15:172-188.

15. Pinheiro C, Penna V, Morais-Santos F, Abrahao-Machado LF, Ribeiro G, Curcelli EC, Olivieri MV, Morini S, Valenca I, Ribeiro D, Schmitt FC, Reis RM, Baltazar F. Characterization of monocarboxylate transporters (MCTs) expression in soft tissue sarcomas: distinct prognostic impact of MCT1 sub-cellular localization. J Transl Med. 2014; 12:118.

16. Halestrap AP. The monocarboxylate transporter familyStructure and functional characterization. IUBMB Life. 2012; 64:1-9.

17. Kirk P, Wilson MC, Heddle C, Brown MH, Barclay AN, Halestrap AP. CD147 is tightly associated with lactate transporters MCT1 and MCT4 and facilitates their cell surface expression. EMBO J. 2000; 19:3896-3904. 
18. Wilson MC, Meredith D, Fox JE, Manoharan C, Davies AJ, Halestrap AP. Basigin (CD147) is the target for organomercurial inhibition of monocarboxylate transporter isoforms 1 and 4: the ancillary protein for the insensitive MCT2 is EMBIGIN (gp70). J Biol Chem. 2005; 280:27213-27221.

19. Slomiany MG, Grass GD, Robertson AD, Yang XY, Maria BL, Beeson C, Toole BP. Hyaluronan, CD44, and emmprin regulate lactate efflux and membrane localization of monocarboxylate transporters in human breast carcinoma cells. Cancer Res. 2009; 69:1293-1301.

20. Pinheiro C, Reis RM, Ricardo S, Longatto-Filho A, Schmitt F, Baltazar F. Expression of monocarboxylate transporters 1,2, and 4 in human tumours and their association with CD147 and CD44. J Biomed Biotechnol. 2010; 2010:427694.

21. Fenske W, Volker HU, Adam P, Hahner S, Johanssen S, Wortmann S, Schmidt M, Morcos M, Muller-Hermelink HK, Allolio B, Fassnacht M. Glucose transporter GLUT1 expression is an stage-independent predictor of clinical outcome in adrenocortical carcinoma. Endocr Relat Cancer. 2009; 16:919-928.

22. Nunes ML, Rault A, Teynie J, Valli N, Guyot M, Gaye D, Belleannee G, Tabarin A. 18F-FDG PET for the identification of adrenocortical carcinomas among indeterminate adrenal tumors at computed tomography scanning. World J Surg. 2010; 34:1506-1510.

23. Deandreis D, Leboulleux S, Caramella C, Schlumberger M, Baudin E. FDG PET in the management of patients with adrenal masses and adrenocortical carcinoma. Horm Cancer. 2011; 2:354-362.

24. Takeuchi S, Balachandran A, Habra MA, Phan AT, Bassett RL, Jr., Macapinlac HA, Chuang HH. Impact of (1)(8) F-FDG PET/CT on the management of adrenocortical carcinoma: analysis of 106 patients. Eur J Nucl Med Mol Imaging. 2014; 41:2066-2073.

25. Bourdeau I, MacKenzie-Feder J, Lacroix A. Recent advances in adrenocortical carcinoma in adults. Curr Opin Endocrinol Diabetes Obes. 2013; 20:192-197.

26. Ribeiro RC, Sandrini F, Figueiredo B, Zambetti GP, Michalkiewicz E, Lafferty AR, DeLacerda L, Rabin M, Cadwell C, Sampaio G, Cat I, Stratakis CA, Sandrini R. An inherited p53 mutation that contributes in a tissue-specific manner to pediatric adrenal cortical carcinoma. Proc Natl Acad Sci U S A. 2001; 98:9330-9335.

27. Latronico AC, Pinto EM, Domenice S, Fragoso MC, Martin RM, Zerbini MC, Lucon AM, Mendonca BB. An inherited mutation outside the highly conserved DNA-binding domain of the p53 tumor suppressor protein in children and adults with sporadic adrenocortical tumors. J Clin Endocrinol Metab. 2001; 86:4970-4973.

28. Parks SK, Chiche J, Pouyssegur J. Disrupting proton dynamics and energy metabolism for cancer therapy. Nat Rev Cancer. 2013; 13:611-623.
29. Ganapathy V, Thangaraju M, Prasad PD. Nutrient transporters in cancer: relevance to Warburg hypothesis and beyond. Pharmacol Ther. 2009; 121:29-40.

30. Fischer K, Hoffmann P, Voelkl S, Meidenbauer N, Ammer J, Edinger M, Gottfried E, Schwarz S, Rothe G, Hoves S, Renner K, Timischl B, Mackensen A, Kunz-Schughart L, Andreesen R, Krause SW, et al. Inhibitory effect of tumor cell-derived lactic acid on human T cells. Blood. 2007; 109:3812-3819.

31. Walenta S, Schroeder T, Mueller-Klieser W. Metabolic mapping with bioluminescence: basic and clinical relevance. Biomol Eng. 2002; 18:249-262.

32. Hunt TK, Aslam RS, Beckert S, Wagner S, Ghani QP, Hussain MZ, Roy S, Sen CK. Aerobically derived lactate stimulates revascularization and tissue repair via redox mechanisms. Antioxid Redox Signal. 2007; 9:1115-1124.

33. Stern R, Shuster S, Neudecker BA, Formby B. Lactate stimulates fibroblast expression of hyaluronan and CD44: the Warburg effect revisited. Exp Cell Res. 2002; 276:24-31.

34. Sonveaux P, Vegran F, Schroeder T, Wergin MC, Verrax J, Rabbani ZN, De Saedeleer CJ, Kennedy KM, Diepart C, Jordan BF, Kelley MJ, Gallez B, Wahl ML, Feron O, Dewhirst MW. Targeting lactate-fueled respiration selectively kills hypoxic tumor cells in mice. J Clin Invest. 2008; 118:3930-3942.

35. Smallbone K, Gavaghan DJ, Gatenby RA, Maini PK. The role of acidity in solid tumour growth and invasion. J Theor Biol. 2005; 235:476-484.

36. Faria AM, Sbiera S, Ribeiro TC, Soares IC, Mariani BM, Freire DS, de Sousa GR, Lerario AM, Ronchi CL, Deutschbein T, Wakamatsu A, Alves VA, Zerbini MC, Mendonca BB, Fragoso MC, Latronico AC, et al. Expression of LIN28 and its regulatory microRNAs in adult adrenocortical cancer. Clin Endocrinol (Oxf). 2015; 82:481-488.

37. Weiss LM. Comparative histologic study of 43 metastasizing and nonmetastasizing adrenocortical tumors. Am J Surg Pathol. 1984; 8:163-169.

38. Fassnacht $M$, Johanssen $S$, Quinkler M, Bucsky $P$, Willenberg HS, Beuschlein F, Terzolo M, Mueller HH, Hahner S, Allolio B, German Adrenocortical Carcinoma Registry G, European Network for the Study of Adrenal T. Limited prognostic value of the 2004 International Union Against Cancer staging classification for adrenocortical carcinoma: proposal for a Revised TNM Classification. Cancer. 2009; 115:243-250.

39. Pinheiro C, Longatto-Filho A, Scapulatempo C, Ferreira L, Martins S, Pellerin L, Rodrigues M, Alves VA, Schmitt F, Baltazar F. Increased expression of monocarboxylate transporters 1, 2, and 4 in colorectal carcinomas. Virchows Arch. 2008; 452:139-146.

40. Pinheiro C, Sousa B, Albergaria A, Paredes J, Dufloth R, Vieira D, Schmitt F, Baltazar F. GLUT1 and CAIX expression profiles in breast cancer correlate with adverse prognostic factors and MCT1 overexpression. Histol Histopathol. 2011; 26:1279-1286. 
41. Queiros O, Preto A, Pacheco A, Pinheiro C, Azevedo-Silva J, Moreira R, Pedro M, Ko YH, Pedersen PL, Baltazar F, Casal M. Butyrate activates the monocarboxylate transporter MCT4 expression in breast cancer cells and enhances the antitumor activity of 3-bromopyruvate. J Bioenerg Biomembr. 2012; 44:141-153.
42. Granja S, Morais-Santos F, Miranda-Goncalves V, VianaFerreira M, Nogueira R, Nogueira-Silva C, Correia-Pinto J, Baltazar F. The monocarboxylate transporter inhibitor alpha-cyano-4-hydroxycinnamic acid disrupts rat lung branching. Cell Physiol Biochem. 2013; 32:1845-1856. 